\title{
PÚRPURA DE HENOCH-SCHÖNLEIN/ VASCULITE POR IMUNOGLOBULINA A: RELATO DE CASO
}

Pôster

Autores deste trabalho:

Rayra Carvalho Maia: Hospital Israelita Albert Einstein

Claudio Arnaldo Len: Universidade Federal de São Paulo (UNIFESP)

Karina Rinaldo: Hospital Israelita Albert Einstein

Área do Trabalho: Pediatria

Data da submissão:15/08/2018 às 19:58

\section{Justificativa}

Púrpura de Henoch-Schönlein (PHS), doença de etiologia indefinida, é a vasculite mais comum da infância, caracterizada por acometimento cutâneo, gastrointestinal, articular e renal. O tratamento varia de acordo com o órgão comprometido. Apresentamos o caso de um paciente com PHS, que evoluiu com acometimento escrotal, apresentação incomum do quadro. Menino, 6 anos, apresentou manchas e pápulas vermelhas em membros inferiores, quinze dias após quadro de resfriado. Evoluiu com edema e artralgia dos tornozelos e aparecimento de púrpuras. Queixouse de dor abdominal e testicular, seis dias após o início dos sintomas necessitando internação no dia seguinte para avaliação da equipe de Reumatologia.

Realizado ultrassom de abdome sem alterações e ultrassom de testículo que evidenciou epididimite à direita. Exames laboratoriais: hemograma, coagulograma e urina 1 normais, proteína $\mathrm{C}$ reativa aumentada.

\section{Objetivo(s)}

INFORMAÇÕES CLÍNICAS Os critérios diagnósticos da Sociedade Europeia de Reumatologia Pediátrica (2005), baseiam-se na púrpura palpável sem trombocitopenia ou coagulopatia associada a, no mínimo, um dos seguintes achados: dor abdominal difusa, artrite ou artralgia, acometimento renal (hematúria e/ou proteinúria) e biópsia de tecido acometido (pele ou rim) com depósito predominante de imunoglobulina A. No caso descrito o paciente apresentou critérios para o diagnóstico, além de comprometimento escrotal, visto em 2 a $38 \%$ dos casos de PHS.

\section{Método(s)}

CONDUTA TERAPÊUTICA Prescrito analgesia com dipirona e metilprednisolona 1 $\mathrm{mg} / \mathrm{kg}$ de 12/12 horas, além de observação clínica.

\section{Resultado(s)}

ACOMPANHAMENTO CLÍNICO Evoluiu com melhora do estado geral, remissão da artralgia, da dor abdominal e testicular, além de clareamento das lesões cutâneas.

Recebeu alta 5 dias após, com prescrição de corticóide e orientações para seguimento devido possibilidade de acometimento renal.

\section{Conclusão (ões)}


Ressalta-se que na vigência de acometimento escrotal, torna- se imprescindível o diagnostico diferencial entre PHS com orquiepididimite e escroto agudo, a fim de evitar procedimentos invasivos desnecessários. 